\section{Humørfylt barnebok om hjernen}

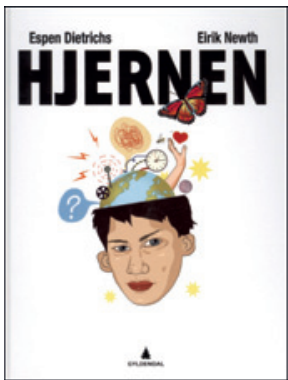

Espen Dietrichs, Eirik Newth

\section{Hjernen}

64 s, ill. Oslo: Gyldendal, 2011. Pris NOK 249 ISBN 978-82-05-39536-7

Nevrologiprofessor Espen Dietrichs og astrofysiker Eirik Newth har sammen skrevet Hjernen. Dette er en faktabok for barn, og forfatterne forklarer anatomi, fysiologi og funksjon uten bruk av medisinske faguttrykk. Språket er tilpasset barn.

Pondusstriper fra humortegner Frode Øverli innleder alle «kapitlene» som er over to sider. Stripene har relevans til kapittelinnholdet og blir av og til også kommentert direkte i kapittelteksten. Kapitlene omhandler f.eks. automatiske bevegelser, hvordan hjernen involveres ved forelskelse, eller hvorfor søvn er viktig.

Layouten er dempet og ryddig og har enkelte faktabokser, slik som denne: «Superkomplisert hjerne. Det er vanlig å si at menneskehjernen er den mest kompliserte vi vet om i naturen. Å forstå hva som skjuler seg i et svart hull i universet er bare barnemat sammenlignet med å fatte hva som skjer i hjernen din når du tenker over det du nettopp har lest.» Enkelte akuttmedisinske tips blir også formidlet, slik som nytten av Heimlich-grepet, og nødvendigheten av akutt sykehusinnleggelse ved hjerneslag.

Denne humørfylte faktaboken for barn og unge vil nok kunne leses av barn fra omkring tiårsalderen. Den har ikke relevans for legers eller studenters virke, men kan være lystig lesing og kanskje gi ideer til formidling av kunnskap til barn om emnet.

En bok for venterommet?

\section{Einar Bryne}

Habiliteringssenteret

Sykehuset i Vestfold

\section{Morsom og spennende barnebok}

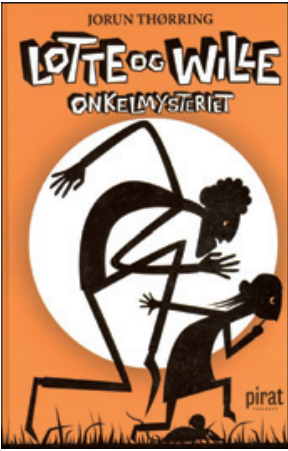

\section{Jorun Thørring}

Lotte og Wille - Onkelmysteriet

144 s, ill. Oslo: Piratforlaget, 2011.

Pris NOK 249

ISBN 978-82-8143-302-1

Gynekologen Jorun Thørring (f. 1955) har skaffet seg et solid navn som krimforfatter både hjemme og ute. I årene 2005-09 utga hun fire bøker i rask rekkefølge. Alle er tidligere omtalt i Tidsskriftet (1). Etter en kort pause er hun nå tilbake, men denne gangen henvender hun seg til langt yngre lesere, nemlig barn mellom 8 og 12 år. Det faller seg derfor naturlig at en representant for målgruppen bidrar til denne omtalen. Et annet interessant poeng er at Thørring har satt seg et ambisiøst mål. Det går ut på at Onkelmysteriet er den første i det som skal bli en serie bøker om de to hovedpersonene Bergljot (Lotte) og Wilhelm (Wille).

Hovedpersonene er et temmelig ulikt par. Med sitt pågangsmot, uredde fremtoning og skarpe tunge er Lotte nesten som en Lisbeth Salander «light». Wille derimot er nysgjerrig, trofast og tillitsfull, godtroende vil man kunne hevde, om det ikke var for måten han takler de sosiale utfordringene han opplever - både fra onkelen som han bor hos, og på skolen. De andre barna ser seg ut Lotte og Wille som to ideelle mobbeofre, men Lotte ordner opp med plageåndene i stor stil. Raskt utvikler det seg et godt kameratskap mellom dem.

Spenningen knytter seg til at det kommer noen skumle menn som har til hensikt å stjele fra butikkene i byen. Lotte og Wille innser at det blir deres oppgave å prøve å sette en stopper for dette. Det tar ikke lang tid før de finner ut at Willes onkel er innblandet, med de forviklinger det skaper for våre helter. Barna roter seg mer og mer inn i flokene, og det blir nesten litt for spennende hver gang de risikerer å bli oppdaget og satt ut av spill. Heldigvis slipper de unna og kan fortsette jakten. Til slutt blir tyvene tatt på fersk gjerning. Noe av det beste med oppklaringen er at Wille får hjelp av Lottes fostermor Stina - siden han nesten blir hjemløs da onkelen blir tatt.

Formatet og forsiden er tiltalende. De mange kapitlene er korte og oversiktlige. Bokstavene er store, så teksten blir lett å lese, og det er mange fine tegninger innimellom. Boken er passe lang, spenningen holdes oppe hele veien, og det er mange morsomme episoder både i barnas møte med mobberne fra skolen og under jakten på tyvene. Litt skummelt er det også når mørket faller på i skogen bak Lottes hus. Innholdet er fantasifullt og overraskende. Handlingen drives godt fremover, og lysten til å lese videre øker underveis. Det er grunn til å glede seg til neste bok i serien.

Even Elias Yuan Hem, 10 år

Geir W. Jacobsen, 65 år

Institutt for samfunnsmedisin

Norges teknisk-naturvitenskapelige universitet

Litteratur

1. Jacobsen G. Aslak Eira er tilbake! Tidsskr Nor Legeforen 2009; 129: 2680. 